\title{
Metachromatic Leukodystrophy Clinical, Biological and Therapeutic Aspects
}

\author{
Ilhem Barboura ${ }^{1}$, Irène Maire ${ }^{2}$, Salima Ferchichi ${ }^{1}$ and Abdelhedi Miled ${ }^{1}$ \\ ${ }^{1}$ Laboratory of Biochemistry, CHU Farhat Hached, Sousse, \\ ${ }^{2}$ Laboratory of Biochemistry Pediatric Debrousse Hospital, Lyon, \\ 1Tunisia \\ ${ }^{2}$ France
}

\section{Introduction}

Scholz's disease or metachromatic leukodystrophy (MLD) is a lysosomal storage disease caused by a deficiency in arylsulfatase A (ARSA: EC 3.1.6.8). This enzyme is responsible for the degradation of sulfatides commonly called cerebroside-3-sulfate or 3-O sulfogalactosylceramide in galactocerebroside and sulfate. The success of hydrolysis of these sphingolipids by ARSA necessarily depends on the presence of saposine B forms a complex with the substrate. The pathological accumulation of sulfatides in the nervous system (myelin, neurons and glial cells) results most often neurological, mental retardation, nervous disorders, blindness. The metachromatic granules accumulated in the central nervous system and peripheral compounds are highly toxic. These are at high levels in the urine of patients affected by the MLD. Arylsulfatase A activity is collapsed in these patients. Unfortunately, the value of enzyme activity is not a predictor of clinical severity of the neuropathology. In contrast, the study of the gene that codes for the ARSA is seen as a way to diagnose the simplest and most reliable of the disease to avoid misdiagnosis due to the presence of pseudodeficit. The conventional therapeutic approaches are essentially symptomatic. They were made in order to restore the enzyme activity of arylsulfatase A and prevent the progression of the pathological accumulation of sulfatides and consequently reduce morbidity associated with MLD.

Key words: arylsulfatase A, metachromatic leukodystrophy, sulfatide, neurological affect.

The sphingolipidoses represent all lysosomal storage diseases that is characterized by the accumulation of sphingolipids essentially in lysosomes and that their etiopathogenic mechanisms are released (Murray et al., 1996).

These disorders are genetically caused by a deficiency of lysosomal protein or its activator (Beaudet et al., 2001). These proteins are involved in the catabolism of sphingolipids, which are complex lipid molecules. They derive from a common structural element, the ceramide. Ceramides are formed by the association of an amino alcohol to 18 carbons in a sphingosine called fatty long-chain acid which are saturated or not, and hydroxylated or not. Sphingosine has a center formed from a hydrophilic primary alcohol, the amine, a secondary alcohol function, and a pole with a hydrophobic acyl chain with a double bond. The structure of various sphingolipids nervous system corresponds to various 
substitutions fixed on the hydroxyl group of carbon 1 of the sphingosine by ester or glycosidic bond (Métais et al, 1980a).

These sulfatide which are the major components of the myelin have the structure of cerebroside sulfate, the sulfo-galactosylceramide whose 3-hydroxyl of galactose is esterified by sulfuric acid which are the more important in this group (Fig. 1. Structure of sulfatide, Cui et al., 2008).

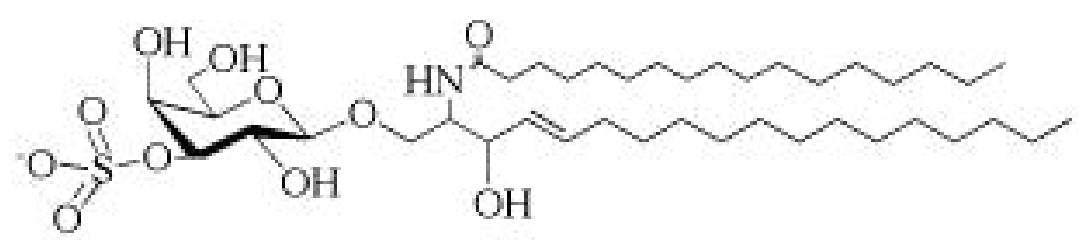

Fig. 1. Structure of sulfatide

The sphingolipidoses are classified according to the nature of the enzyme deficiency and substrate accumulated (Table1. Classification of the main Sphingolipidosis, Borel et al., 1999)

\begin{tabular}{|c|c|c|c|}
\hline Disease & Deficient enzyme & Accumulated products & Symptoms \\
\hline Gaucher disease & $\beta$-Glucosidase & Glucosylceramide & $\begin{array}{c}\text { Hepatosplenomegaly, } \\
\text { Mental retardation, Bone } \\
\text { pain }\end{array}$ \\
\hline Krabbe disease & $\begin{array}{l}\text { Galactocerebrosyl- } \\
\beta \text {-galactosidase }\end{array}$ & Galacosylceramide & $\begin{array}{l}\text { Mental retardation, } \\
\text { Neurodenegeration, } \\
\text { Decerebration-like }\end{array}$ \\
\hline Fabry disease & a-galactosidase & Globotriaosylceramide & $\begin{array}{l}\text { Ischemic infarction in } \\
\text { affected organs, } \\
\text { Angiokeratomas } \\
\text { hypohidrosis, Mental } \\
\text { retardation }\end{array}$ \\
\hline $\begin{array}{l}\text { Tay-Sachs } \\
\text { disease }\end{array}$ & Hexosaminidase A & GM2-ganglioside & $\begin{array}{c}\text { Neurodegeneration, } \\
\text { Developmental disability, } \\
\text { kidney and skin disorders }\end{array}$ \\
\hline $\begin{array}{l}\text { Metachromatic } \\
\text { leukodystrophy }\end{array}$ & Arylsulfatase A & Sulfatide & $\begin{array}{c}\text { Demyelinisation } \\
\text { in CNS and PNS, Mental } \\
\text { retardation }\end{array}$ \\
\hline $\begin{array}{l}\text { Niemann-Pick } \\
\text { disease }\end{array}$ & Sphingomyelinase & Sphingomyelin & $\begin{array}{l}\text { Hepatosplenomegaly, } \\
\text { Mental retardation }\end{array}$ \\
\hline
\end{tabular}

Table 1. Classification of the main Sphingolipidosis 
A great clinical and biological heterogeneity characterizes these metabolic diseases. Various Clinical forms, severe or moderate, may correspond to same enzyme deficiency, which explains the diagnosis difficulty of these disorders (Von Figura et al., 2001).

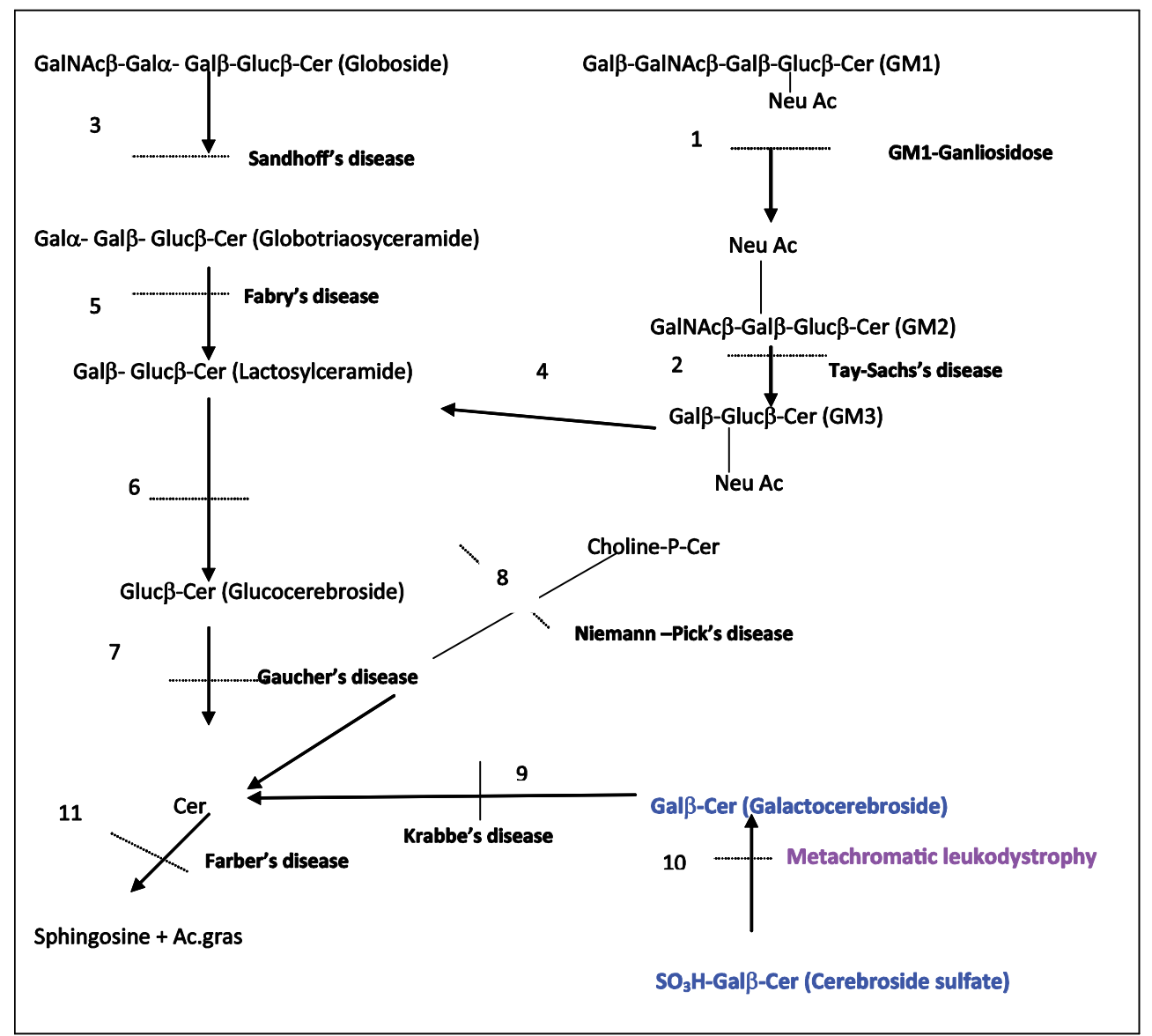

Fig. 2. Catabolism of sphingolipids and enzyme deficiencies responsible for sphingolipidoses. 1 : gangliosido- $\beta$-galactosidase $; 2$ : $\beta$-hexosaminidase $\mathrm{A} ; 3: \beta$ hexosaminidase $A$ et $B ; 4$ : neuraminidase $; 5: \alpha$-galactosidase $A ; 6:$ lactosyl-ceramide- $\beta$ galactosidase $; 7$ : cerebroside- $\beta$-glucosidase $; 8$ : sphingomyelinase $; 9$ : cerebroside- $\beta$ galactosidase ; 10 : arylsulfatase A ; 11 : ceramidase.

Metachromatic leukodystrophy (MLD) is a sphingolipidosis which corresponds to the loss of myelin in areas normally myelinated ago (Maria et al., 2003). The MLD or Scholz's disease was discovered by Scholz Greenfield in 1925. This is a recessive autosomal disease. This encephalopathy, which results from a deficiency of arylsulfatase A (ARSA, EC 3.1.6.8) is 
involved in sulfatides hydrolysis to galactosyl-cerebroside and sulfate (Fig.2. Catabolism of sphingolipids and enzyme deficiencies responsible for sphingolipidoses, Métais et al, 1980b).

The accumulation of these toxic metabolites is the origin of lesions in the white matter in central and peripheral nervous system (Logowska et al., 2005). Some Rare cases of MLD are due to saposin B deficiency: sphingolipid activator protein B (Sap-B) (Deconinck et al., 2008).

The existence of arylsulfatase A pseudodeficiency in 7 to $15 \%$ of the population is causing by a collapsed ARSA activity without clinical signs (Bognar et al., 2002). The incidence of the MLD varies from 1 / 40000 to 1 / 100 000. For Habbanites Jews, it's estimated at 1.3 percent (Kolodny \& Fluharty, 1995a).

\section{Clinical presentation}

Clinically, three phenotypes were distinguished: Late infantile, juvenile and adult form. These phenotypes vary according to the absence or presence of neurological manifestations and their progression degree. The late infantile form is the most severe and frequent form, accounting for $60 \%$. The symptoms appear before $4^{\text {th }}$ age. The motor regression starts at the age of walking. Intellectual abilities are preserved until installing a state of terminal decerebration with pyramido-extrapyramidal syndrome.

Reflexes tendon's abolition is found early and reflects the association of peripheral neurological signs, the death often occurs 2-4 years after initial diagnosis (Kolodny \& Fluharty, 1995b). The juvenile form symptoms (20 to 30\% of cases) occurs between 4 and 16 years manifested most often by behavioral and walking disorders. It is characterized by a decreases in intellectual performance, emotional difficulties and language disorders. The motor regression is progressive. The majority of patients die at the age of 10 years, but survival is sometimes possible to more than 20 years (Maire et al., 2007). On the adult form (10 to $20 \%$ of cases) the symptoms occurs between 16 and 60 years, with a variable speed of evolution. The patient has generally a change of personality, behavior disorders, and then a decrease in intellectual and professional performance, memory loss and dementia (Bauman, 2002; Turpin, 1994a).

\section{Pathophysiology of MLD}

The sulfatides accumulate in the central and peripheral nervous systems are highly toxic compounds which found in high concentrations in the urine of patients affected by MLD (Whitufield et al., 2001). It was demonstrated that metachromatic granules accumulate in many organs: gall bladder, liver, pancreas, ovaries and lymph nodes.

The renal tubular epithelium is usually affected, they can be also found in the eye, in the dental pulp. Microscopically the demyelination is diffuse. It mainly affects the cerebral hemispheres, fibrillary gliosis is important. The metachromatic granules are alcianophiles, they can be extracellular and can also be situated on glial cells or macrophages. The deposit can reach 20 to 30 microns in diameter. However, these granules are more numerous in most affected white matter regions, but the gray matter is normal. The Peripheral nerve is always 
affected by observing segmental demyelination and metachromatic substance deposits in Schwann cells, are showed in electron microscopy. (Turpin et al., 1994b)

\section{The cerebroside-sulfatase (CSS) or cerebroside 3-sulfatase or arylsulfatase $A$ (ARSA)}

The arylsulfatase A is belongs to the sulfatases family. These sulfatases ensure the hydrolysis of esters sulfate such that O-sulfates and $\mathrm{N}$-sulfates with different specific substrates. In humans, there are 17 small sulfatases, 500 to 800 amino acids; ARSA protein has 507 amino acids. These enzymes are characterized by structural homology to the entire sequence, particularly in the $\mathrm{N}$-terminal region. They have also a similar active site. The catalytic site of ARSA is located in a positively charge pocket and it acts as a ligand involving magnesium. The active site of this enzyme contains a helices that surround a large $\beta$ sheet. The dissulfure bridge (SS) is located between the aspartate (Asp335) and arginine (Arg370) residue. The sulfatases require posttranslational oxidation affecting cysteine leading to the formation of aldehyde which will facilitate theproduction of formyl glycine (FGL). Diez Roux and Ballabio showed that FGL is essential for the catalytic activity of the enzyme. (Cesani, 2009a; Diez-Roux \& Ballabio, 2005a; Schestag, 2002).

The quaternary structure is $\mathrm{pH}$-dependent; at neutral $\mathrm{pH}$, the structure is dimeric, where as at lysosomal $\mathrm{pH}$ (acidic) homo-octameric form is predominant which formed by four dimmers.

The ARSA structure analysis is important to understanding the mutations and the genotype phenotype correlation studies. The ARSA is encoded by a gene located on 22q13.

Stein et al. have been cloned and sequenced the human ARSA gene. It spans 3,2 Kb genomic DNA and is separated into eight exons ranging in size from 116 to $362 \mathrm{bp}$. The ARSA gene is transcribed into three mRNA species of different sizes (2.1, 3.7 and $4.8 \mathrm{~kb}$ ) (Lukatela et al., 1998).

\section{Phenotype/genotype relationship}

Since the identification of ARSA gene, more than 118 mutations have been described so far. Many point mutations (missense and non sense), many substitutions, splicing mutations, and some deletions and insertions have been reported (Cesani, 2009b). However, most common mutations in the general population: the IVS2 + 1G> A mutation which associated with the late infantile form, the P426L mutation is frequently associated with the juvenile form, I179S mutation is associated with adult form and pseudodeficiency: N350 and $1524+95$ A $\rightarrow$ G (poly A-) (Clouter-Mackie \& Gagnier, 2003). The distinction between the three phenotypes of MLD in the literature (late infantile, juvenile and adult form) posed a major problem for clinicians because they had just the age of clinical signs onset to typing different MLD forms. Recently, according to the study of Biffi et al., it is possible to establish phenotype-genotype relationship.

These authors proposed a classification of clinical forms of MLD based on the genotype, residual enzyme activity and the study of the expression of mutated proteins (Biffi et al., 2008). 


\section{Biological diagnosis}

Various explorations are necessary in any acquired encephalopathy case resulting psychomotor regression. The biochemical diagnosis includes the following studies:

\subsection{Urinary sulfatide analysis}

The study of urinary excretion of sulfatides is possible by thin layer chromatography or spectrometry mass (Colsch et al., 2008).

\subsection{Enzymatic study}

The Confirmatory diagnosis is based on the demonstration of the ARSA deficiency. The determination of enzyme activity can be made on leukocytes circulating blood of sick patients, or skin fibroblasts in culture. The measurement of enzyme activity is possible by colorimetric method using a Synthetic substrate: paranitrocathechol sulfate (Dubois et al., 1975). However, the collapsed enzyme activity is not a predictor factor of MLD clinical severity. The study of heterozygotes subjects by measurement of enzyme activity is limited because there is an overlap between the values of ARSA activity in normal and heterozygotes subjects. The multiple sulfatase deficiency (MSD) leds to many problems in the result's interpretation (Diez-Roux \& Ballabio, 2005b). In some clinically healthy subjects or suffering from neurological diseases other than MLD, the value of enzyme activity observed may be low, for the existence of the pseudodefeciency alleles. These alleles represent $7-15 \%$ of alleles in the general population. Two mutations described are responsible for that: N350 (PD1) $152495 \mathrm{~A} \rightarrow$ G or poly A-(PD2). ARSA pseudodeficiency must be recognized to avoid misdiagnosis like for prenatal diagnosis in families where coexists one allele of MLD (Polten et al., 1991a).

\subsection{Molecular diagnosis}

Molecular diagnosis of MLD is the more accurate and uses samples more stable than those used for determining enzyme activity. This diagnosis can contribute to the identification of common mutations in the ARSA gene especially in the heterozygous subjects (Polten et al., 1991b). Genomic DNA was extracted from leukocytes, and was amplified by PCR (polymerase chain reaction) using oligonucleotide primers already described. Patients or their parents were screened for the presence of the most frequent MLD causal mutation by restriction endonuclease digestion and sequencing.

\subsection{Prenatal diagnosis}

Prenatal diagnosis is the best way to put heterozygous couple, especially in a who had couple already an affected child (index case). Two methods are proposed, the amniocentesis and chorionic amniocentesis. The chorionic villous biopsy is performed upon $8^{\text {th }}$ or $9^{\text {th }}$ week of pregnancy. This technique provides rapid results (maximum 3 days). Amniocentesis is achievable in the 14th week of gestation. Diagnostic confirmation is always performed after measurement of enzyme activity in amniotic cells crop, which will delay the results 3-4 weeks. Currently, the identification of fetal genotype and predicting the type of the disease 
even in the absence of family history has become easier with the use of molecular technologies (Maire, 2004).

\section{Treatment}

\subsection{Bone Marrow Transplant (BMT)}

The BMT reconstitute the hematopoietic system of patient with stem cells from a healthy donor. Several patients with infantile and juvenile form of MLD received BMT. No signs of regression have been reported, with the exception of a child who had a neurological improvement post-BMT, but the BMT in patients with adult form was very beneficial. Improvement of neurological symptoms associated with a normalization of their ARSA activities and their sulfatide rate was noted. The post-BMT survival in patients suffering from adult form is estimated at 77\% (Krivit et al., 2001).

\subsection{Enzyme replacement}

Enzymatic Therapy is to administer to the patient the active deficient enzyme which is responsible for his illness. Recently in Denmark, a test of enzyme replacement therapy was offered to children with the late infantile form. The clinical trial includes the study of safety and tolerance in the first phase. Patients are then followed in the second phase to study the dose-response. The enzyme which used in the test is similar to the human enzyme. To assess the Metazym ${ }^{\circledR}$ effect, the nervous system of patients has been evaluated at the beginning of therapy and after 6 to 12 months. These evaluations include MRI, cognitive tests, measurements of nerve conduction and motor function (Dali \& Lund, 2009).

\subsection{Substrate-reduction therapy with warfarin}

The warfarin is an anticoagulant and an antagonist of vitamin $\mathrm{K}$, The first Warfarin studies in mice showed that this compound inhibits the synthesis of sphingolipids leading to sulfatide reducing (Crowther et al., 2009).

\subsection{Gene therapy}

Gene therapy involves introducing into the body patient's a normal version of the defective gene which responsible of his illness. To date, several approaches are tested in animal models (Consiglio et al., 2000).

\section{Conclusion}

Metachromatic leukodystrophy is a sphingolipidosis caused by arylsulfatase A deficiency. This enzyme catalyses the first degradation step of the sulfatide.

Several mutations were identified in the ARSA gene which abolish the catalytic activity and may reduce the ARSA stability. Thus, the study of the ARSA gene three-dimensional structure associated with the search for the mutations responsible of MLD could establish phenotype-genotype relationship. 


\section{Acknowledgment}

We thank so much Dr Abdelhedi Miled and Pr.Ag Ferchichi Salima for their help to do this work and for their collaboration.

\section{References}

Baumann, N.; Turpin, J.C. \& Lefever, M. (2002). Motor and psychocognitive clinical types in adult metachromatic leukodystrophy: genotype/phenotype relationship? J Physiol, Vol.96, pp. 301-6.

Beaudet, A.L.; Sly, W.S. \& Valle, D. (2001). The Metabolic and Molecular Bases of Inherited Diseases. In : Scriver CR, ed. McGraw-Hill, New York.

Biffi,A.; Cesani, M. \& Fumagalli, F. (2008). Metachromatic leukodystrophy - mutation analysis provides further evidence of genotype-phenotype correlation. Clin Genet, Vol.74, pp. 349-57.

Bognar, S.K.; Furac, I. \& Kubat, M. (2002). Croatation population Data for arylsulfatase A pseudodeficiency-associated mutations in healthy subjects, and in patients with Alzheimer-type dementia and down syndrome. Arch Med Res, Vol. 33, pp. 473-7.

Borel, J.P.; Maquart, F.X. \& Gillery, P.H. (1999) Exposite M. mécanismes moléculaires et chimiques à l'origine des maladies, In Biochimie pour le clinicien, Frison-Roche, Paris.

Cesani, M.; Capotondo, A. \& Plati, T. (2009). Charaterisation of new arylsulfatase A gene mutations reinforces genotype-phenotype correlation in metachromatic leukodystrophy. Hum Mutat, Vol.30, pp. 936-45.

Clouter-Mackie, M.B. \& Gagnier L. (2003). Spectrum of mutations in the arylsulfatase A gene in a Canadian collection including two novel frameshift mutations, a ion (C488R) and an MLD mutation (R84) in cis with a pseudodeficiency allele. Mol Genet Metab, Vol.79, pp. 91-8.

Colsch, B.; Afonso, C. \& Turpin, J.C. (2008). Sulfogalactosylceramides in motor and psychocognitive adult metachromatic leukodystrophy: relations between clinical, biochemical analysis and molecular aspects. Biochim Biophys Acta, Vol.1780, pp. 43440.

Consiglio, A.; Quattrini, E. \& Martino, S. (2000). In vivo gene therapy of metachromatic leukodystrophy by lentiviral vectors correction of neuropathology and protection against learning impairment in affected mice. Nat Med, Vol.7, pp. 310-6.

Crowther, M.A.; Ageno, W. \& Garcia, D. (2009). Oral vitamin K versus placebo to correct excessive anticoagulation in patients receiving warfarin: a randomized trial. Ann Intern Med, Vol.150, pp. 293-300.

Cui, Y.; Colsch, B. \& Afonso, C. (2008). Synthetic sulfogalactosylceramide (sulfatide) and its use for the mass spectrometric quantitative urin metachromatic leukodystrophies. Glycoconjugate J, Vol. 25, pp. 147-55.

Dali, C. \& Lund, A.M. (2009). Thérapie enzymatique substitutive par intraveineuse pour la leukodystrophie metachromatique (MLD). Congrès"Annual Clinical Genetics Meeting", Tampa, Floride (USA), 25-29 mars. 
Deconinck, N.; Messaaoui, A. \& Ziereisen, F. (2008). Metachromatic leukodystrophy without arylsulfatase A deficiency: a new case of saposin-B deficiency. Eur J Paediatr Neurol, Vol.12, pp. 46-50.

Diez-Roux, G. \& Ballabio, A. (2005). Sulfatases and human disease. Ann Rev Genomics Hum Genet, Vol.6, pp. 355-79.

Dubois, G.; Turpin, J.C. \& Baumann, N. (1975). Absence of ASA activity in healthy father of metachromatic leukodystrophy (MLD) patient. N Eng J Med, Vol.293, p. 302.

Kolodny, E.H. \& Fluharty, L. (1995). Metachromatic leukodystrophy and multiple sulfatase deficiency : sulfatide lipidosis. In : Scriver CR, Beaudet, A.L.; Sly, W.S. \& Valle, D. eds. The metabolic and molecular bases of inherited disease. McGraw-Hill, New York, pp. 2693-739.

Krivit, W.; Saphiro, E. \& Peters, C. (2001). Adult metachromatic leukodystrophy treated by bone marrow transplantation in 18 patients. SSIEM 39th Annual Symposium Pargue, Czech Republic, 4-7 september. J Inheri Dis, Vol. 24, p. 103.

Lugowska, A.; Berger, J. \& Tylki-Szyman'ska, A. (2005). Molecular and phenotypic characteristics of metachromatic leukodystrophy patients from Poland. Clin Genet, Vol. 68, pp. 48-54.

Lukatela, G.; Krauss, N. \& Theis, K. Crystal structure of human arylsulfatase A: the aldehyde function and the metal ion at the active site suggest a novel mechanism for sulphate ester hydrolysis. (1998). Biochem, Vol.11, pp. 3654-64.

Maire, I. (2004). Diagnostic prénatal (DPN) des maladies héréditaires du métabolisme (MHM). Biotribune, Vol.12, pp. 56-9.

Maire, I.; Caillaud, C. \& Froissart, R. (2007). Diagnostic biologique et moléculaire des maladies de surcharge lysosomale. Atlas des maladies de surcharge lysosomales. VML, retrieved from «www.vml-asso.org »

Maria, B.L.; Deidrick, K.M, \& Moser, H. (2003). Leukodystrophies: pathogenesis, diagnosis, strategies, therapies, and future research directions. J Child Neurol, Vol. 18, pp. 57890.

Métais, P. ; Agneray, J. \& Férard, G. (1980). Biochimie clinique, Biochimie métabolique. Simep, Paris.

Murray, R.K.; Grannier, D.K. \& Mayes, P.A. (1996). Précis de biochimie de Harper. (23e édition américaine). Laval : Presse de l'université.

Polten, A.; Fluharty, A.L. \& Fluharty, C.B. (1991). Molecular basis of different forms of metachromatic leukodystrophy. N Engl J Med, Vol.324, pp. 18-22.

Schestag, F.; Yaghootfam, A. \& Habetha, M. (2002). The functional consequences of missense mutations affecting an intra-molecular salt bridge in arylsulfatase $A$. Biochem J, Vol.367, pp. 499-504.

Turpin, J.C.; Gray, F. \& Baumann N. (1994). Leucodystrophies. Encyclopédie MédicoChirurgicale, Neurologie, Elsevier, 17-076-D-10. Paris

Whitfield, P.D.; Sharp, P.C. \& Johnson DW. (2001). Characterisation of urinary sulfatides in metachromatic leukodystrophy using electrospray ionisation-tandem masse spectrometry. Mol Genet Metab, Vol.73, pp. 30-7. 
Von Figura, K.; Gieselmann, J. \& Jaeken, J. (2001). Metachromatic leukodystrophy. In: Scriver CR, Beaudet, A.L.; Sly, W.S, \& Valle, D. eds. The Metabolic and molecular bases of inherited disease. McGraw-Hill, pp. 3695-724, New York. 


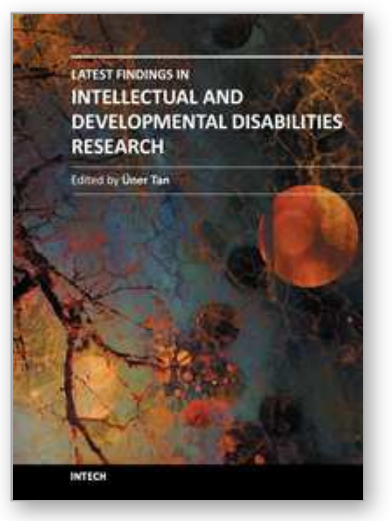

\author{
Latest Findings in Intellectual and Developmental Disabilities \\ Research \\ Edited by Prof. Uner Tan
}

ISBN 978-953-307-865-6

Hard cover, 404 pages

Publisher InTech

Published online 15, February, 2012

Published in print edition February, 2012

Intellectual and Developmental Disabilities presents reports on a wide range of areas in the field of neurological and intellectual disability, including habitual human quadrupedal locomotion with associated cognitive disabilities, Fragile $X$ syndrome, autism spectrum disorders, Down syndrome, and intellectual developmental disability among children in an African setting. Studies are presented from researchers around the world, looking at aspects as wide-ranging as the genetics behind the conditions to new and innovative therapeutic approaches.

\title{
How to reference
}

In order to correctly reference this scholarly work, feel free to copy and paste the following:

Ilhem Barboura, Irène Maire, Salima Ferchichi and Abdelhedi Miled (2012). Metachromatic Leukodystrophy Clinical, Biological and Therapeutic Aspects, Latest Findings in Intellectual and Developmental Disabilities Research, Prof. Uner Tan (Ed.), ISBN: 978-953-307-865-6, InTech, Available from:

http://www.intechopen.com/books/latest-findings-in-intellectual-and-developmental-disabilitiesresearch/metachromatic-leukodystrophy-clinical-biological-and-therapeutic-aspects

\section{INTECH}

open science | open minds

\section{InTech Europe}

University Campus STeP Ri Slavka Krautzeka 83/A 51000 Rijeka, Croatia Phone: +385 (51) 770447 Fax: +385 (51) 686166 www.intechopen.com

\section{InTech China}

Unit 405, Office Block, Hotel Equatorial Shanghai No.65, Yan An Road (West), Shanghai, 200040, China 中国上海市延安西路65号上海国际贵都大饭店办公楼405单元 Phone: +86-21-62489820

Fax: +86-21-62489821 
(C) 2012 The Author(s). Licensee IntechOpen. This is an open access article distributed under the terms of the Creative Commons Attribution 3.0 License, which permits unrestricted use, distribution, and reproduction in any medium, provided the original work is properly cited. 